\title{
KUASA IDEOLOGI ORGANISASI KEAGAMAAN DALAM NOVEL $A D A M$ HAWA DAN TUHAN IZINKAN AKU MENJADI PELACUR KARYA MUHIDIN M DAHLAN SERTA RELEVANSINYA PADA BAHAN AJAR MATA KULIAH KRITIK SASTRA
}

\section{THE POWER OF RELIGIOUS ORGANIZATION IDEOLOGY IN ADAM HAWA AND TUHAN IZINKAN AKU MENJADI PELACUR NOVELS WRITTEN BY MUHIDIN M DAHLAN WITH THE RELEVANCY IN LITERARY CRITICISIM COURSE TEACHING MATERIALS}

\author{
Taswirul Afkar ${ }^{1 *}$, Wiwik Mardiana ${ }^{2}$ \\ Pendidikan Bahasa dan Sastra Indonesia, Universitas Islam Majapahit, Indonesia ${ }^{1}$ \\ Pendidikan Bahasa Inggris, Universitas Islam Majapahit, Indonesia ${ }^{2}$ \\ taswirulafkar@unim.ac.id $^{1}$, wiwik.mardiana@unim.ac.id ${ }^{2}$ \\ *Penulis Korespondensi
}

\begin{tabular}{ll}
\hline Info Artikel & ABSTRAK \\
\hline Sejarah artikel: & Tujuan penelitian ini untuk mendeskripsikan hegemoni ideologi organisasi \\
Diterima: & keagamaan dalam novel Adam Hawa dan Tuhan Izinkan Aku Menjadi \\
1 November 2020 & $\begin{array}{l}\text { Pelacur karya Muhidin M Dahlan (Gus Muh). Hasil identifikasi ini } \\
\text { Direvisi: }\end{array}$ \\
memiliki relevansi dengan Capaian Pembelajaran Mata Kuliah (CPMK) \\
29 November 2020 & Kritik Sastra. Penelitian ini berjenis kualitatif dengan pendekatan sosiologi \\
Disetujui: & sastra. Analisis menggunakan analisis isi. Hasil penelitian menunjukkan \\
15 Januari 2021 & bahwa hegemoni ideologi dalam organisasi keluarga dan keagamaan \\
& berbentuk patriarki dan materialisme. Oleh karena itu, kedua novel \\
Kata kunci: & berpotensi sebagai bahan ajar mata kuliah Kritik Sastra pada kompetensi \\
Hegemoni, Sastra, & keterampilan umum dan khusus. \\
Pendidikan &
\end{tabular}

\begin{tabular}{ll}
\hline Article Info & ABSTRACT \\
\hline Article history: & This research aims to describe ideological hegemony in Adam Hawa and \\
Received: & Tuhan Izinkan Aku Menjadi Pelacur written by Muhidin M Dahlan (Gus \\
1 November 2020 & Muh). The result of the study has relevance with the learning outcomes of \\
Revised: & the literary criticism course. This research is qualitative with sociology \\
29 November 2020 & literature approach. Content analysis is used in the analysis. The result of \\
Accepted: & the research shows that the ideological hegemony in family and religious \\
15 January 2021 & $\begin{array}{l}\text { organization are in forms of patriarchy and materialism. It means that these } \\
\text { novels are potential in teaching materials for literary criticism course on } \\
\text { beth specific and general skill competences. }\end{array}$
\end{tabular}

Hegemony,

Literature, Education

Copyright (C) 2021, Stilistika: Jurnal Pendidikan Bahasa dan Sastra DOI: http://dx.doi.org/10.30651/st.v14i1.6401

\section{PENDAHULUAN}

Mantan anggota komunitas pembenci Pancasila yang menganggap bahwa perusakan tempat ibadah agama lain sebagai tindakan yang luhur, Muhiddin M Dahlan (selanjutnya disebut Gus Mus) telah berhasil melepaskan diri dari doktrinasi radikalisme beragama. Berbekal kesadaran, ia mulai 
melakukan evaluasi diri dengan jalan memanfaatkan kekuatan dan ketajaman pena untuk menggugah alam bawah sadar dalam menyebarkan kebaikan. Gus Muh menggugat dengan sastra.

Sastra tidak bisa dilepaskan dari kehidupan manusia karena sastra dalam takaran tertentu merupakan representasi aktivitas manusia. Hal tersebut sesuai pendapat Wellek (2014) yang menyatakan bahwa sastra menampilkan kehidupan tetapi sastra bukanlah kehidupan itu sendiri. Gus Muh, novelis yang lahir tahun 1978 asal Sulawesi memberi warna baru di dunia sastra Indonesia dengan karya yang menampilkan Adam Hawa (AH) dan Tuhan Izinkan Aku Menjadi Pelacur (TIAMP).

Novel AH dan TIAMP meninggalkan kesan pada pembaca berupa sanggahan, kecaman, dan kutukan. Organisasi keagamaan di Indonesia melayangkan surat teguran dan memberikan gelar Nabi Kegelapan bagi Gus Muh. Terlepas dari respon pembaca, Gus Muh mungkin bisa dilihat dalam konteks memberikan kritik terhadap praktik yang dilakukan oleh sebagian organisasi keagamaan sehingga dapat terjadi perubahan yang menurut pandangan Gus Muh dapat lebih baik. Hal ini sesuai pendapat Stanton (2012) yang mengatakan bahwa kejelian pengarang dalam menghadirkan sudut pandangnya membutuhkan keseksamaan yang bertujuan untuk menimbulkan efek yang sesuai.
Gus Muh mengangkat fenomena masyarakat berupa rasa memiliki pengetahuan beragama, menjadi pemimpin organisasi keagamaan, dan memiliki jamaah fanatik yang membuat seseorang menilai dirinya sebagai kebenaran. Melihat diri sebagai kebenaran bukanlah hal yang baik. Menilai kebenaran diperlukan pengetahuan, mengingat letaknya ada dalam pemikiran dan hubungan kekuasaan yang luas. Hal ini sesuai dengan pendapat Heryanto (2018) yang menyatakan bahwa kebenaran ideologis dan otoritas itu luas, terus berubah, dan rumit di masyarakat.

Ideologi organisasi keagamaan dapat tersebar tersamar melalui penyebaran ilmu agama. Tanpa sadar, ideologi ini hadir di antara masyarakat. Pada novel AH misalnya, ajaran Adam sebagai putra Tuhan disebarkan melalui keagamaan menjadi hal menarik. Ideologi ini mampu memperdaya tiga perempuan yakni tokoh Maya, Hawa, dan Marfuah. Sedangkan pada novel TIAMP, ditampilkan organisasi jamaah dalam merekrut anggota melalui ilmu agama. Ajaran ini mampu menarik minat jamaah untuk mengeluarkan uang pribadi dan aktivitas dakwah dalam mendapatkan anggota baru.

Hegemoni ideologi keluarga dan organisasi jamaah menjadi topik pembahasan. Sumber daya manusia sebagai bahan pembentuk ideologi dianalisis menggunakan konsep ideologi Althusser (2010) yang meliputi pemberian upah, reproduksi keahlian, dan ketundukan. Ketiga hal ini dideteksi melalui Ideological State Apparatus (ISA) maupun Repressive State Apparatus (RSA). Sedangkan untuk menentukan hubungan 
hegemoni ideologi, digunakan analisis Model of Determination of Class milik Erik Olin Wright (1978) yang mencakup tiga aspek yakni: 1) class structure, 2) class formation, 3) class struggle. Ketiga aspek membutuhkan media penghubung dalam interaksinya. Media penghubung tersebut adalah: 1) limitation yang membatasi kemungkinan kepentingan lain. 2) selection yang membatasi ruang lingkup kepentingan, dan 3) transformation yaitu praktik sosial yang mengubah batasan kepentingan yang telah ditentukan sebelumnya. 4) mediation yang muncul akibat hadirnya kepentingan lain. Penulis berani mengambil risiko dengan melakukan kreasi untuk mengadaptasi konsep-konsep yang ada tersebut untuk melakukan analisis dalam konteks organisasi-organisasi yang ada di dalam masyarakat.

Penelitian ini sebenarnya merupakan bentuk pengembangan penelitian yang dilakukan Afkar (2009) yang membahas aspek kekuasaan dalam novel Tuhan Izinkan Aku Menjadi Pelacur. Penelitian tersebut mendeskripsikan hegemoni kekuasaan masyarakat sipil yakni organisasi melalui proses internal dan eksternal. Perbedaan penelitian ini dengan penelitian sebelumnya terletak pada penambahan objek kajian yakni novel Adam Hawa selain novel Tuhan Izinkan Aku Menjadi Pelacur.

Penelitian tentang konsep hegemoni pernah dilakukan oleh Setyo J (2018) dengan judul Terorisme Islamic State of Iraq and Syria (ISIS) dalam Novel Habibi Da'isyi Karya Hajar 'Abdu As-Samad: Analisis Hegemoni Gramsci. Penelitian berbentuk tesis ini mengungkap bahwa adanya organisasi teroris yang menyamarkan diri mengunakan kedok 'Jihad' untuk menarik simpatisan masyarakat umum. Hal ini memiliki pembeda dengan penelitian yang dilakukan di dalam artikel ini yakni membahas formasi praktik hegemoni ideologi organisasi yang mengatasnamakan agama.

\section{METODE}

Berjenis penelitian deskriptif kualitatif, penelitian ini dilakukan dengan pendekatan sosiologi sastra. Kutipan kalimat atau paragraf yang mengandung unsur hegemoni ideologi dijadikan data penelitian dengan teknik pengumpulan pustaka atau dokumen. Validasi data menggunakan trianggulasi teori sehingga mampu mendapatkan data yang bisa dipertanggungjawabkan. Teknik analisis data menggunakan analisis isi (content analysis) yang menekankan kajian makna berupa tafsir ideologi organisasi yang mengatasnamakan agama. Hal ini sesuai pemdapat Endraswara (2006) yang menyatakan bahwa tujuan analisis isi untuk membuat inferensi yang diperoleh melalui identifikasi dan penafsiran.

Data diolah mengikuti prosedur sebagai berikut: (1) penyusunan kartu data, hal ini dimaksudkan untuk mempermudah dalam pengelolaan jenis data berdasarkan item fokus penelitian, (2) kodifikasi data memberikan label berupa identitas kuasa organisasi agama/ ideologi/ tahun terbit dan halaman sumber data/ nomor urut data, dan (3) analisis teks melalui penafsiran analisis isi, hasil tersebut dijabarkan dalam bentuk deskripsi terkait hegemoni ideologi organisasi keagamaan. 


\section{HASIL DAN PEMBAHASAN}

Karya fiksi AH menampilkan tokoh Adam sebagai manusia pertama ciptaan Tuhan. Maia, tokoh perempuan dipercaya Adam sebagai ciptaan Tuhan menjadi pelayan dan teman setia di Taman Eden. Adam memiliki peraturan yang merugikan Maia sebagai perempuan sehingga memilih pergi dengan penuh dendam. Selanjutnya Hawa menjadi perempuan yang memenuhi keinginan Adam. Perempuan terakhir di kehidupan Adam adalah Marfuah. perempuan muda itu dikirim Maia untuk balas dendam. Adam meninggal dibunuh.

Nidah Kirani dalam novel TIAMP berkarakter kuat dalam menegakkan Islam di Indonesia. Sehingga ia tertarik bergabung dengan organisasi jamaah. Kekecewaan muncul karena ketidakcocokan dirinya dengan pimpinan organisasi jamaah dalam diskusi agama dan banyak kejanggalan di jemaah. Hal ini pada mulanya berdampak pada semangat ibadah Nidah dan akhirnya melahirkan efek yang buruk. Nidah kemudian menjadi wanita yang mengutuk Tuhan dan agamanya.

Analisis atas AH dan TIAMP memerlukan pembacaan berulang dalam menemukan praktik hegemoni ideologi. Hal ini dilakukan untuk menemukan wilayah praktiknya. Organisasi keagamaan dalam menyebarkan ilmu agama sebagai alat manipulasi pembentuk hegemoni dalam struktur organisasi tertentu menjadi isi cerita novel $\mathrm{AH}$ dan TIAMP. Organisasi keagamaan muncul di lingkungan masyarakat sipil yang mandiri. Organisasi ini mewujudkan keinginan masyarakat dalam memahami Tuhan tanpa pengaruh pemerintah maupun swasta. Hal tersebut sesuai pernyataan
Bockock (2007) bahwa wilayah hegemoni terbagi ke dalam tiga wilayah yaitu swasta, negara, dan masyarakat sipil.

Kemandirian yang tampak atas organisasi keagamaan dalam $\mathrm{AH}$ dan TIAMP sebenarnya tidak bersifat mutlak mandiri. Organisasi membutuhkan peran swasta dan negara dalam pemenuhan kebutuhan bahan pokok dan kebijakan pemerintah dalam membentuk lembaga. Saling membutuhkan membuka peluang terjadinya hegemoni ideologi secara internal lembaga maupun antarlembaga. Hal ini sesuai pendapat Patria (2015) yang menyebutkan bahwa ekonomi, negara, dan masyarakat sipil menjadi elemen konstruksi hegemoni yang sifatnya saling berhubungan namun juga parsial mengingat masing-masing ranah memiliki lembaga yang mewakilinya sehingga tingkat analisisnya bisa terjadi dalam lembaga dan/atau organisasi dalam batas ranah yang variatif.

Kesadaran anggota organisasi keagamaan menjadi dasar praktik hegemoni. Faktor kesadaran ada dalam aspek pengetahuan dan kepatuhan. Aspek ini membuat batasan bagi anggota dalam memahami realitas. Keterbatasan tersebut membentuk kepatuhan anggota menjadi masyarakat neriman. Berikut ini adalah temuan dan pembahasan praktik hegemoni ideologi organisasi keagamaan yang mengatasnamakan Tuhan dan memanipulasi agama dalam karya fiksi AH dan TIAMP.

\section{Formasi Kuasa Agama sebagai Praktik Hegemoni Ideologi Patriarki dalam Novel AH}

Di dalam karya fiksi AH, ajaran yang diturunkan Tuhan malah 
dijadikan alat oleh karakter fiktif Adam dalam mendapatkan perempuan. Pengakuan Adam sebagai putra Tuhan membentuk skema hegemoni ideologi secara ISA dan RSA untuk perempuan. Hal ini tampak pada skema berikut.

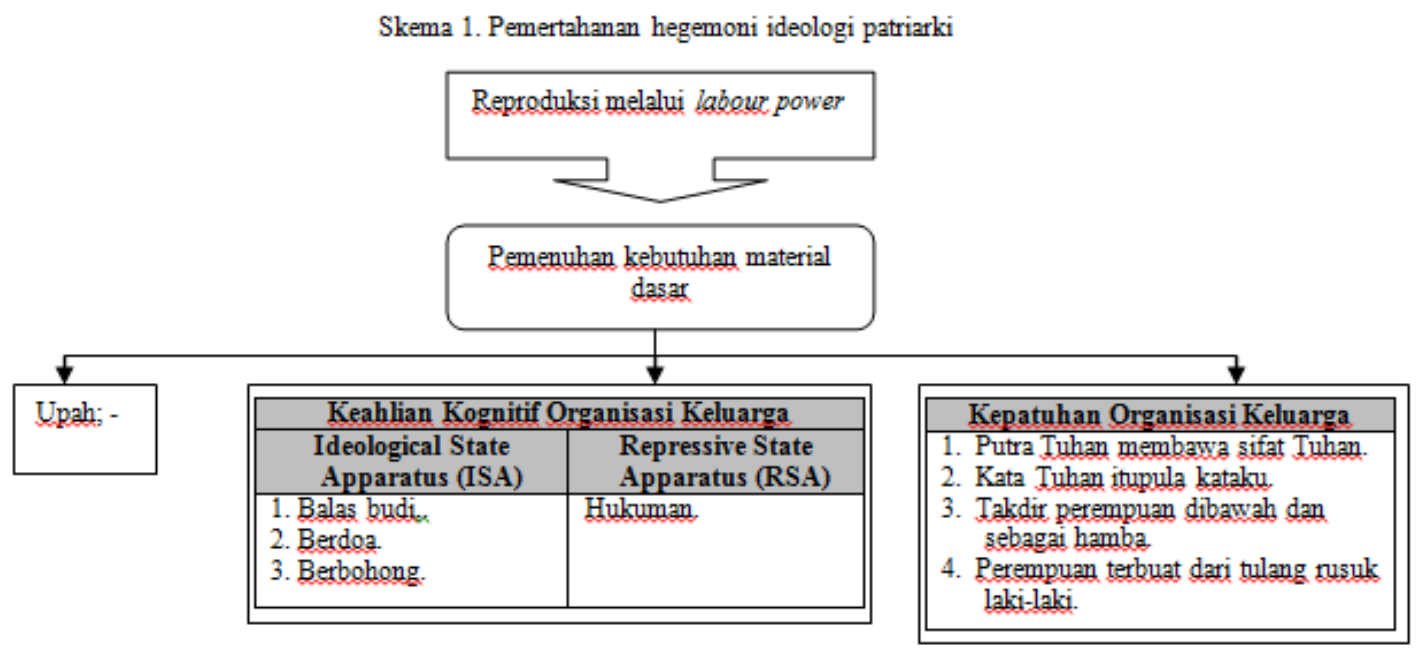

$\begin{array}{ccr} & \text { Ideologi patriarkis tokoh Adam } \\ \text { dalam } & \text { karya fiksi yang }\end{array}$ mencampuradukkan tradisi metafisika Barat dan ideologi feminis ini ditampilkan dalam suasana naratif yang mengajarkan keistimewaan lakilaki tanpa cela dan kewajiban. Prosesnya melibatkan peran ISA dan RSA dalam praktik hegemoni. Praktik dialog persuasif ISA dalam keluarga dilakukan Adam melalui balas budi, berdoa, dan berbohong. Proses dialog dititikberatkan pada aspek kognitif untuk memberikan dampak patuh anggota keluarga terhadap ideologi patriarki, di antaranya; 1 . Putra Tuhan membawa sifat Tuhan, 2. Kata Tuhan itu pula kataku, 3. Takdir perempuan di bawah dan sebagai hamba, 4 . Perempuan terbuat dari tulang rusuk laki-laki. Sedangkan RSA ditampilkan dalam bentuk hukuman akibat gagalnya dialog persuasif ISA.

Perekrutan anggota keluarga diterapkan melalui ISA dan RSA sebagai usaha dalam menjalankan proses pembentukan sumber daya manusia di organisasi keluarga. Pembentukan ini mampu melanggengkan hegemoni ideologi patriarki dengan mudah. Hal tersebut sesuai dengan pernyataan Althusser (2010:10) bahwa reproduksi sumber daya manusia tampil sebagai sine qua non yang melibatkan reproduksi interaksi keahlian hingga mampu menyentuh bahkan membentuk kepatuhan ideologis. Kondisi ini dilakukan dalam mempertahankan tatanan ideologi patriarki sehingga anggota keluarga termanipulasi alam bawah sadarnya untuk total mematuhi dan menaati.

Penjelasan berikut berkaitan interaksi hegemoni ideologi patriarki. Penyajiannya ditampilkan dalam bentuk skema untuk mengungkap hegemoni ideologi patriarki sebagaimana dapat dilihat dalam skema berikut: 
Skema 2 agama sebagai arena

hegemoni ideologi patriarki

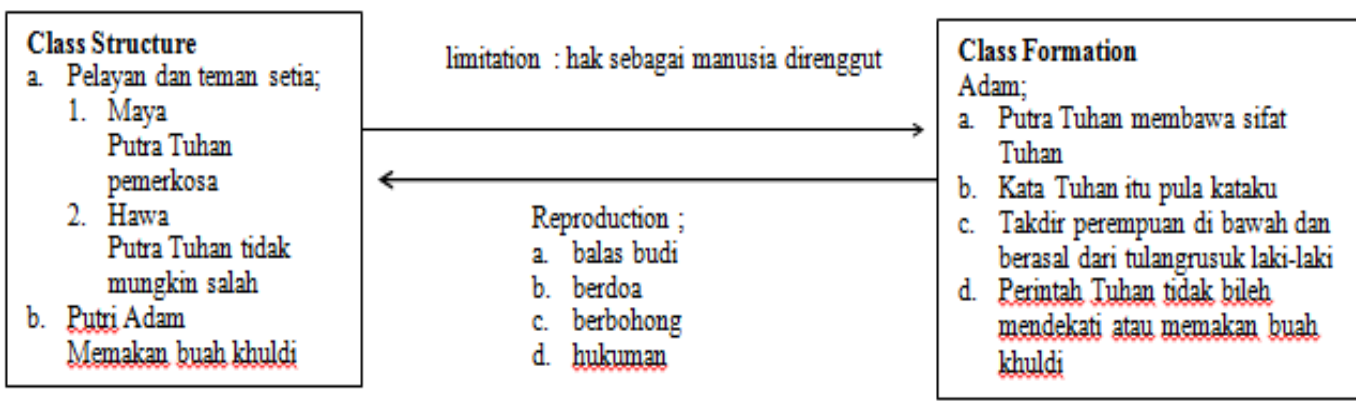

Dominasi karakter fiktif Adam di dalam class formation tertampilkan melalui interaksi hegemoni ideologi patriarki secara tidak terstruktur. Hal ini bisa dilihat dari skema 2 yang tidak memunculkan class struggle. Padahal kelas ini memiliki fungsi penting dalam proses dialog persuasif ISA yakni sebagai mediasi berkaitan penyamaan persepsi antar class formation dan structure. Ketiadaan class struggle kemungkinan besar terjadi RSA dalam pembentukan hegemoni ideologi patriarki.

Keberhasilan ISA terlihat pada pembentukan class structure yang menjadikan karakter fiktif dalam novel ini, Hawa, sebagai pelayan dan teman setia. Manipulasi pembentukan kesadaran Hawa dalam memahami putra Tuhan tidak mungkin salah dan harus selalu dipatuhi, dilakukan melalui dialog persuasif ISA yang meliputi balas budi, berdoa, dan berbohong. Perhatikan kutipan berikut:

Dan ia sangat tahu, satu-satunya senjata dari manusia sebatang kara dan payah seperti dirinya adalah doa dan rapalan harapan. (KK/PAT/2017.55/7)

Sebab Adam sangat yakin, alasan balas budi adalah alasan penaklukan dan tak mudah ditolak perempuan. (KK/PAT/2017.62/10)

Satu-satunya cara menghadapi Hawa yang kerap matanya terpancing untuk melihat lama gambar-gambar yang terpotret dengan tak teratur dan seperti sengaja dirusak itu dengan cara berbohong. (KK/PAT/2017.67/13)

Class formation menggunakan ISA dalam pembentukan hegemoni ideologi. Pembentukan ini dimaksudkan untuk memanipulasi kesadaran Hawa menjadi pelayan dan teman setia tanpa syarat. Adam menyadari bahwa dia adalah manusia sebatang kara setelah Maya tiada. Berdoa menjadi langkah strategis untuk memohon kepada Tuhan agar diberikan solusi. Tuhan mengirim Hawa menjadi teman hidup Adam. Perlahan-lahan Adam menunjukkan kuasa melalui dialog persuasif tentang balas budi yang dikemas dengan mengatasnamakan Tuhan. Adam juga membohongi Hawa berkaitan dengan gambar perempuan yang ada di dinding rumah. Dialog persuasif ISA dilakukan Adam terus-menurus sehingga mampu membentuk Hawa sebagai pelayan dan teman setia.

Kegagalan ISA terjadi pada Maya sebagai pelayan dan teman setia 
Adam. Gagalnya dialog persuasif class formation memunculkan variasi kesadaran pada class structure. Arus limitation berkaitan dengan variasi kesadaran yang memunculkan hak manusia yang telah direnggut (lihat skema 2). Munculnya variasi kesadaran menandai gagalnya dialog persuasif hegemoni ideologi. Hal ini sesuai dengan pendapat Sugiono (2016) yang menyatakan bahwa munculnya perbedaan menandai kegagalan kuasa ideologi dalam praktik dialektik secara halus.

Arus limitation dari konstruk class structure sebagai akibat perilaku bohong yang dilakukan dalam class formation. Arus ini sebagai wujud protes hak manusia dan ajaran Tuhan yang disampaikan dalam proses class formation mengenai perempuan diciptakan dari rusuk laki-laki adalah bohong. Dialog persuasif antarkelas menyajikan perselisihan dalam mempertahankan argumen masingmasing pihak. Akibatnya Maya memilih meninggalkan dominasi class formation dengan penuh dendam dan menilai Adam sebagai putra Tuhan pemerkosa. Langkah yang diambil dalam meredam arus limitation baru yakni melalui tindakan RSA. Tindakan represif/RSA sebagai akibat tidak patuhnya class structure terhadap larangan Tuhan yakni mendekati atau memakan buah khuldi. Munah sebagai putri Adam telah melakukan larangan Tuhan. Munah dijatuhi hukuman mati dan jasadnya tidak dikubur.

Dominasi class formation mengalami kebuntuan dalam interaksi antarkelas. Hal ini disebabkan ketidakberdayaan Adam dalam menghadapi perempuan muda dari class structure bernama Marfuah. Perhatikan skema berikut:

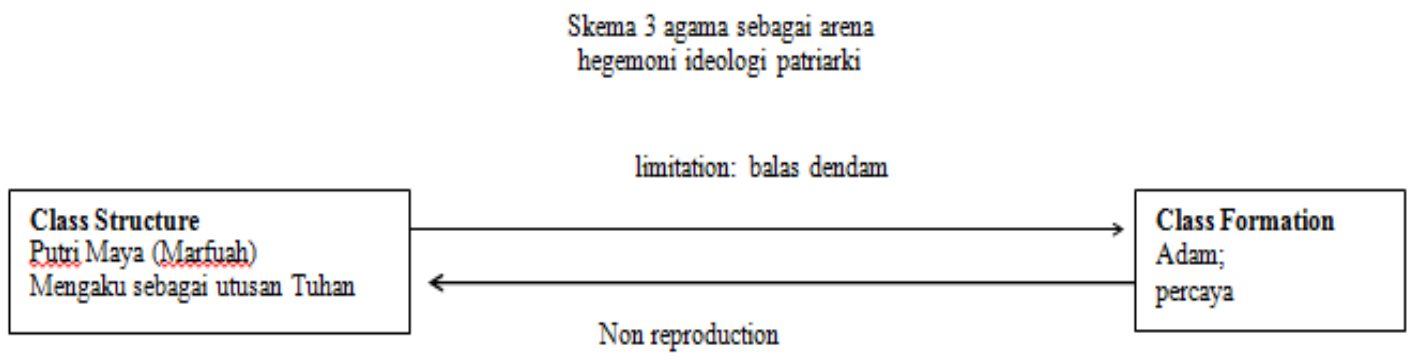

Marfuah hadir dalam wilayah dominasi Adam sebagai bentuk lanjutan pemberontakan class structure yang dimulai oleh Maya. Tiadanya class struggle membuat class formation tidak memiliki arus transformation berupa informasi bahaya yang mengintai.

Marfuah sebagai perempuan muda hadir dalam dominasi Adam. Kecantikan dan pengakuan Marfuah sebagai utusan Tuhan mampu menghentikan reproduction yang dilakukan Adam. Inilah untuk pertama kali class structure mampu meruntuhkan dominasi class formation secara penuh dan menjadi akhir kehidupan Adam.

\section{Formasi Kuasa Agama sebagai Praktik Hegemoni Ideologi Materialisme dalam Novel TIAMP}

Semangat masyarakat dalam memahami Tuhan menjadi peluang organisasi keagamaan dalam membangun organisasi. Agama 
dijadikan daya tarik Organisasi Jamaah dalam mendapatkan anggota dan menggemukkan kas organisasi. Interaksi persuasif ISA dilakukan mengatasnamakan agama dalam rangka memanipulasi dan membentuk ketundukan ideologis anggota jamaah. Berikut skema persuasif ISA dalam hegemoni ideologi Organisasi Jamaah:

Skema 4. Pemertahanan hegemoni ideologi materialism

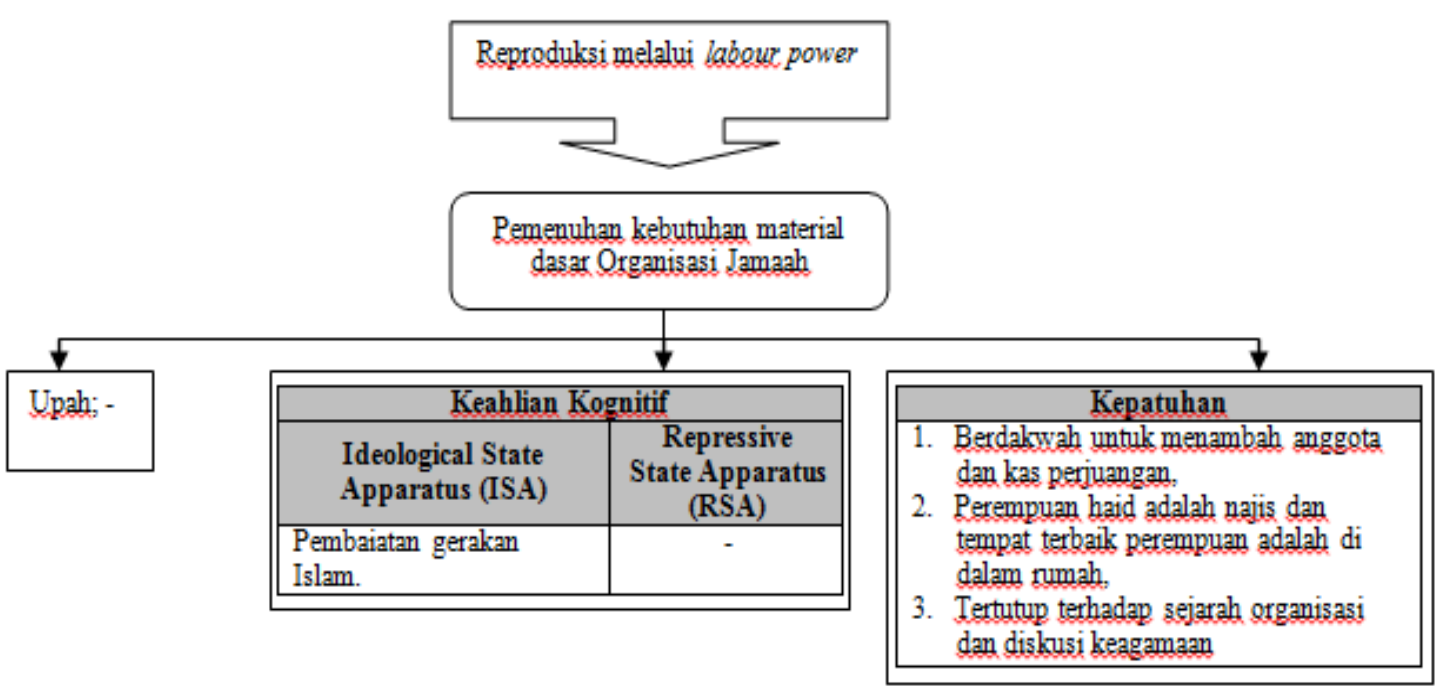

Ideologi Organisasi Jamaah mengajarkan keutamaan dakwah untuk mendapatkan anggota baru dan uang kas. Prosesnya menggunakan ISA dalam praktik hegemoni. Dialog persuasif ISA dalam Organisasi Jamaah dilakukan melalui pembaiatan. Baiat ini untuk membentuk kepatuhan anggota jamaah terhadap ideologi materialisme, di antaranya: 1 . Berdakwah untuk menambah anggota dan kas perjuangan, 2. Perempuan haid adalah najis dan tempat terbaiknya di dalam rumah, 3. Tertutup terhadap sejarah Organisasi Jamaah dan diskusi keagamaan. Perekrutan anggota jamaah diterapkan melalui ISA sebagai proses dalam membentuk kepatuhan pada organisasi jamaah. Pembentukan ini untuk melanggengkan hegemoni ideologi materialisme. interaksi hegemoni ideologi materialisme. Penyajiannya berbentuk skema untuk mengungkap hegemoni ideologi materialisme yang ada pada Organisasi Jamaah. Perhatikan skema berikut: 


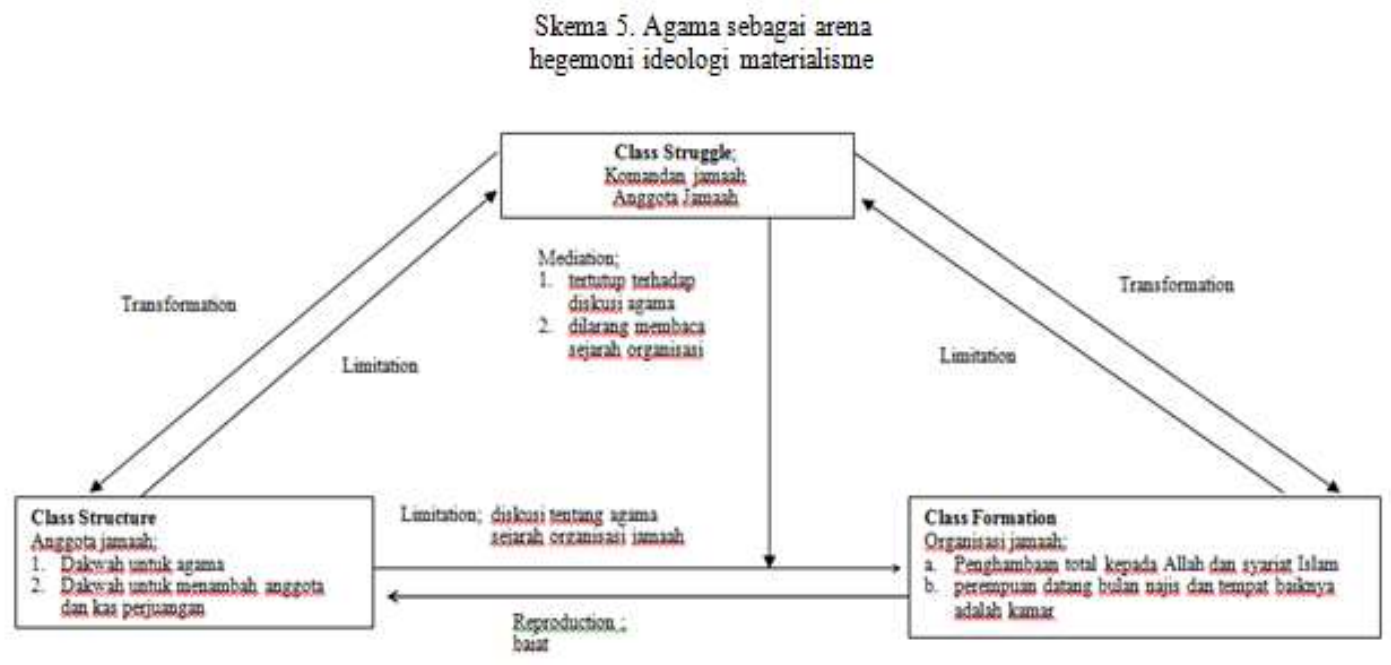

Kuasa Organisasi Jamaah sebagai class formation menjalankan interaksi hegemoni ideologi materialisme secara terstruktur. Hal ini bisa dilihat skema 5. Menggunakan class formation sebagai kuasa Organisasi Jamaah, class struggle ditempati komandan jamaah dan anggota jamaah, sedangkan class structure tempat anggota jamaah.

Dialog persuasif ISA mengenai agama dilakukan class formation mampu membentuk hegemoni ideologi materialsme pada class structure. Dakwah Organisasi Jamaah mengenai penghambaan total kepada Allah dan syariat Islam dan perempuan datang bulan najis sehingga tempat terbaik perempuan adalah di kamar. Dakwah ini mampu membentuk kepatuhan melalui dialog persuasif baiat.

Makna baiat yang dimunculkan di dalam novel ini mengadaptasi dan memanipulasi ajaran Islam. Adaptasi ini digunakan untuk sumpah setia tidak berpindah gerakan Islam selain Organisasi Jamaah. Hal ini membuat persuasif ISA membentuk ketundukan class structure dalam menjalankan dakwah untuk kepentingan Organisasi Jamaah.
Praktik class struggle dalam mengawasi aktivitas pembentukan hegemoni ideologi materialisme dilakukan dengan cara bertamu dan terlibat langsung. Pengawasan ini dilakukan oleh komandan dan anggota senior. Perhatikan kutipan teks berikut:

Saban sore, aku bertemu dengan tamu-tamu ikhwan dan salah satunya adalah komandan. ...Kutanyakan apa pandangannya tentang sufi. Jawabannya sangat ketus. "Ngapain kamu nanyananya begitu. Belum waktunya." (KOJ/MAT/2006.63-64/25)

"Hei Mbak Kiran, untuk apa kamu membaca buku-buku seperti itu." ...

"Aku saja sudah lima tahun tidak selancang kamu."

(KOJ/MAT/2006.84/27)

Dialog persuasif ISA dalam aktivitas bertamu setiap sore di kontrakan rumah anggota jamaah. Hal ini merupakan cara pertama class struggle dalam mengawasi dan memastikan transformation berjalan dengan baik. Diterimanya komandan jamaah sebagai tamu menandakan 
pembentukan hegemoni ideologi materialisme berjalan dengan baik.

Cara kedua terlibat langsung dalam keseharian class structure. Strategi pengawasan terlibat langsung yakni dengan otomatisasi fungsi kelas. Ada keunikan berkaitan otomatisasi fungsi kelas sebagai pengawas. Status anggota jamaah jika sudah bergabung selama lima tahun akan memiliki kuasa terhadap anggota lain sehingga fungsi otomatis kelas bergeser tempat dari class structure menjadi class struggle.

Munculnya arus limitation dari class structure akibat larangan dan tertutupnya tindakan class struggle. Variasi kesadaran arus limitation anggota jamaah sebagai protes hak-hak sebagai anggota jamaah. Hak ini berkaitan pengetahuan sufi dan sejarah organisasi jamaah. Tanggapan class struggle yang ketus dan tertutup membuat dialog persuasif antarkelas tidak berfungsi. Anggota jamaah memilih untuk diam dan meninggalkan kekecewan sehingga memicu arus limitation. Perhatikan kutipan teks berikut:

Setahuku, aku yang paling keras berdakwah menggaet satu dua tiga orang di Kampus Barek yang umumnya ukhti. ...Aku harus mengeluarkan uang paling minim 500 ribu setiap minggunya untuk kas (KOJ/MAT/2006.60/18)

Variasi kesadaran menilai bahwa ada ketidaksesuaian tujuan Organisasi Jamaah dalam memahami Allah. Kekecewaan terjadi pada Class structure melalui arus limitasi dakwah untuk kepentingan materialisme berupa menambah anggota dan kas perjuangan.

\section{Relevansi Kuasa Organisasi Keagamaan sebagai Bahan Ajar Mata Kuliah Kritik Sastra}

Capaian pembelajaran mata kuliah kritik sastra terdiri beberapa kompetensi di antaranya: 1) Kompetensi sikap dan tata nilai berindikator menunjukan sikap religius yang mencerminkan nilai sosial akademik, 2) Kompetensi pengetahuan mencakup penguasaan konsep dasar kritik sastra hegemoni ideologi, 3) Kompetensi keterampilan secara umum mampu menemukan hegemoni ideologi dalam mengimplementasi ilmu kritik sastra dan secara khusus mampu mengapresiasi karya sastra Indonesia secara tulis. Standar minimal perumusan capaian ini sesuai dengan pernyataan Suwandi (2016) yang mengemukakan bahwa sikap dan tata nilai, pengetahuan, serta keterampilan umum khusus dijadikan dasar dalam capaian pembelajaran program studi Pendidikan Bahasa Indonesia.

Kompetensi keterampilan khusus membutuhkan latihan berulang sehingga pelaksanaannya memerlukan aktivitas membuat kritik sastra. Wujud kritik sastra memiliki acuan penulisan ilmiah yakni berdasarkan pada konsep dan teknik dalam kajiannya. Hal ini sesuai pernyataan Mahayana (2015); Gasong (2018) yang mengemukakan bahwa kritik sastra mewujudkan pengamatan rasional terhadap karya sastra dengan prosedur ilmiah yang berupa deskripsi, analisis, atau komparatif. Prosedur ini membentuk aktivitas kritik sastra yang memunculkan nilai kemanusiaan masyarakat yang berada dalam karya sastra. Hal ini juga sesuai dengan pendapat Hardiningtyas (2008) yang menyebutkan bahwa belajar sastra 
memiliki prinsip menanamkan nilai humanis.

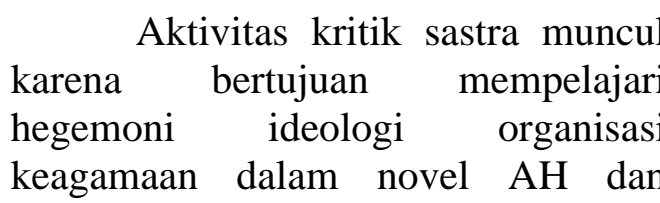
TIAMP. Kritik hegemoni ideologi organisasi keagamaan memiliki nilai tawar potensial. Bahan ajar mata kuliah Kritik Sastra pada materi analisis kritik sastra akademik menjadi media alternatif untuk memahami hegemoni ideologi dalam karya sastra.

Idealisme mahasiswa yang tinggi membuatnya melupakan bersikap kritis terhadap organisasi keagamaan. Novel AH dan TIAMP menampilkan tindakan koreksi terhadap organisasi keagamaan. Kritik hegemoni ideologi sebagai bahan ajar dapat diimplementasikan pada mata kuliah Kritik Sastra dengan capaian pembelajaran mata kuliah (CPMK) keterampilan umum dan khusus yang berupa: 1. Kemampuan menerapkan nilai humanis dalam mengimplementasi ilmu pengetahuan dan teknologi dalam bidang kritik sastra, dan 2. Kemampuan mengapresiasi karya sastra Indonesia secara lisan dan tulis.

\section{PENUTUP}

Novel AH dan TIAMP memiliki skema unik dalam formasi hegemoni ideologi patriarki dan materialisme. Manipulasi terhadap ajaran agama dilakukan dalam organisasi keluarga dan organisasi keagamaan untuk membentuk hegemoni sesuai dengan ideologi tertentu, di antaranya:

1. Hegemoni berideologi patriarki. Praktiknya menggunakan; a) ISA meliputi; balas budi, berdoa, dan berbohong. b) RSA dalam bentuk hukuman. Interaksi kelas dilakukan tidak terstruktur.

2. Hegemoni berideologi materialisme. Praktiknya menggunakan ISA melalui baiat. Sedangkan interaksi kelas dilakukan terstruktur.

\section{UCAPAN TERIMA KASIH}

Penelitian ini dapat dilaksanakan dengan baik berkat bantuan dari berbagai pihak. Peneliti mengucapkan terimakasih kepada Direktorat Penelitian dan Penelitian kepada Masyarakat Ristek Dikti nomor kontrak 187/SP2H/LT/DRPM/2020 yang telah menyediakan dana terlaksananya penelitian dan bagi LLDIKTI VII nomor 037/SP2H/LTMONO/LL7/2020 dan LP4MP Universitas Islam Majapahit nomor 02/LP4MP/UNIM/K/IV/2020 dalam tugasnya memantau kemajuan dan kualitas penelitian yang kami lakukan.

\section{DAFTAR PUSTAKA}

Afkar, T. (2009). Aspek Kekuasaan Dalam Memoar Tuhan Izinkan Aku Menjadi Pelacur Karya Muhiddin M Dahlan (Kajian Hegemoni Antonio Gramsci). Surabaya: Universitas Negeri Surabaya.

Althusser, L. (2010). Tentang Ideologi: $\quad$ Marxisme Strukturalis, Psikoanalisis, Cultural Studies. Yogyakarta: Jalasutra.

Bocock, R. (2007). Pengantar Komprehensif Untuk Memahami Hegemoni. Yogyakarta \& Bandung: Jalasutra. 
Dahlan, M. M. (2006). Tuhan Izinkan

Aku Menjadi Pelacur! Memoar Luka Seorang Muslimah. Yogyakarta: Scripta Manent.

Dahlan, M. M. (2017). Adam Hawa. Yogyakarta: Scripta Manent.

Endraswara, S. (2006). Metodologi Penelitian Sastra: Epistemologi, Model, Teori, Dan Aplikasi. Yogyakarta: Pustaka Widyatama.

Gasong, D. (2018). Kritik Sastra. Yogyakarta: Deepublish.

Hardiningtyas, P. (2008). Implementasi Pengajaran Sastra Indonesia Di Sekolah: Upaya Pemahaman Pembelajaran Berbasis Kompetensi Dan Pendekatan Kontekstual. Jurnal Aksara. Denpasar: Slamat Trisila.

Heryanto, A. (2018). Identitas Dan Kenikmatan Politik Budaya Layar Indonesia. Jakarta : Kepustakaan Populer Gramedia.

Mahayana, M. S. (2015). Kitab Kritik Sastra. Jakarta: Pustaka Obor Indonesia.
Patria, N. \&. (2015). Antonio Gramsci Negara \& Hegemoni. Yogyakarta: Pustaka Pelajar.

Setyo J, R. (2018). Terorisme Islamic State Of Iraq And Syria (ISIS) dalam Novel Habibi Da'isyi Karya Hajar 'Abdu As-Samad: Analisis Hegemoni Gramsci. UGM: Yogyakarta.

Stanton, R. (2012). Teori Fiksi. Yogyakarta: Pustaka Pelajar.

Sugiono, M. (2006). Kritik Antonio Gramsci Terhadap Pembangunan Dunia Ketiga. Yogyakarta: Pustaka Pelajar Offset.

Suwandi, S. \&. (2016). Capaian Pembelajaran Dan Standar Nasional Pendidikan Bahasa Indonesia. Surakarta: Yuma Pustaka.

Wellek, R. \&. (2014). Teori Kesusastraan. Jakarta: Gramedia Pustaka Utama.

Wright, E. O. (1985). Classes. London: Verso. 